\title{
KANDUNGAN FRAKSI SERAT SILASE KULIT PISANG KEPOK (Musa paradisiaca) DENGAN PENAMBAHAN LEVEL DEDAK DAN LAMA PEMERAMAN YANG BERBEDA
}

\author{
S. HANDAYANI., A. E. HARAHAP DAN E. SALEH \\ Fakultas Pertanian dan Peternakan Universitas Islam Negeri Sultan Syarif Kasim RiauKampus Raja Ali Haji \\ Jl. H.R. Soebrantas KM. 15 Pekanbaru \\ Email : sarihdyn@gmail.com
}

\begin{abstract}
Banana peels not much optimally used as a substitute for grass. In 2014 the production of banana peels waste in Riau province reached 7.586 ton. More than a third of the banana that has not been used in the strip were banana peels. The purpose of this study was to determine the effect of different rice bran level and fermentation time to the fiber fraction silage that included the content of neutral detergent fiber (NDF), acid detergent fiber (ADF), acid detergent lignin (ADL), hemicellulose, and cellulose. This research was held at the Laboratory of Nutrition Science and Chemistry, Faculty of Agriculture and Animal Science State Islamic University of Sultan Syarif Kasim Riau Pekanbaru. The research was done in April until September 2016. This study used a completely randomized design Factorial consisting of rice bran level $(0 ; 5 ;$ and $10 \%)$ and fermentation time $(0 ; 14 ;$ and 28 days), each treatment was repeated 2 times. There were no significant differences $(P>0,05)$ in $N D F, A D F, A D L$, hemicelluloses, and cellulose. It can be concluded that there is not interaction between rice bran level and fermentation time toward fiber fraction of banana peels silage.
\end{abstract}

Keywords : fiber fraction, silage, banana peels, rice bran, fermentation time

\section{PENDAHULUAN}

Pakan berfungsi untuk memenuhi kebutuhan ternak baik untuk hidup pokok, pertumbuhan, reproduksi dan produksi. Tiga faktor penting dalam kaitan penyediaan hijauan bagi ternak ruminansia adalah ketersediaan pakan harus dalam jumlah yang cukup, mengandung nutrisi yang baik dan berkesinambungan sepanjang tahun. Ketersediaan hijauan umumnya berfluktuasi mengikuti pola musim, dimana produksi hijauan melimpah dimusim hujan dan sebaliknya terbatas di musim kemarau. Terbatasnya ketersediaan pakan dimusim kemarau, maka penyediaan pakan yang berkualitas dapat disiasati dengan memanfaatkan limbah.

Pisang kepok (Musa paradisiaca) merupakan jenis pisang yang pada umumnya sering diolah terutama dalam olahan makanan. Sepertiga dari bagian buah pisang adalah limbahnya yaitu kulit pisang. Berdasarkan data Badan Pusat Statistik dan Direktorat Jenderal Hortikultura diketahui produksi pisang Provinsi Riau tahun 2014 mencapai 22.758 ton, dan limbah yang dihasilkan mencapai 7.586 ton (Badan Pusat Statistik, 2014).

Kulit pisang kepok sangat potensial sebagai pakan karena terdapat dalam jumlah yang cukup banyak dan mengandung zat gizi yang cukup baik. Menurut Koni dkk., (2013) terdapat 18,71\% serat kasar kulit pisang kepok. Kulit pisang kepok merupakan bahan berserat tinggi yang tersusun oleh beberapa komponen diantaranya selulosa, lignin dan hemiselulosa. Selulosa merupakan komponen utama penyusun dinding sel tanaman dan hampir tidak pernah ditemui dalam keadaan murni di alam, melainkan berikatan dengan bahan lain yaitu lignin dan selulosa membentuk lignoselulosa (Lynd et al., 2002). 
Kandungan serat kasar yang tinggi dalam bahan pakan perlu dilakukan proses silase. Silase merupakan salah satu cara meminimumkan kehilangan nutrien dan perubahan nilai nutrisi suatu bahan pakan pada kondisi an aerob (McDonald et al., 1981).

Faktor yang mempengaruhi kualitas silase yaitu : (1) karakteristik bahan (kandungan bahan kering, kapasitas buffer, struktur fisik dan varietas), (2) tata laksana pembuatan silase (besar partikel, kecepatan pengisian ke silo, kepadatan pengepakan dan penyegelan silo), (3) keadaan iklim (misalnya suhu dan kelembaban) (Bolsen dan Sapienza, 1993).

Proses silase juga melibatkan kerja dari bakteri asam laktat (BAL). Orlajensen (1994) mengemukakan BAL memiliki sifat antara lain gram positif, tidak memiliki spora, tidak berbentuk motil, berbentuk batang dan tidak memiliki organisme katalase.

Bahan yang digunakan sebagai aditif dalam pembuatan silase adalah dedak. Fungsi dedak dalam proses silase adalah sebagai bahan pemadat dan pengikat, di samping itu penambahan dedak dalam substrat akan dimanfaatkan oleh Bakteri Asam Laktat sebagai sumber energi (Gunawan, 1975). Menurut Riswandi, (2014) silase eceng gondok dengan penambahan dedak 5\% dapat menurunkan kandungan serat kasar dibandingkan dengan tanpa penambahan dedak. Bhia, dkk (2015) menyatakan lama pemeraman menggunakan nira lontar selama 6-18 hari dapat meningkatkan kadar ADF, NDF, selulosa dan lignin kulit kopi.

Tujuan dari penelitian ini adalah untuk mengetahui kualitas fraksi serat yang terkandung dalam silase kulit pisang kepok (Musa paradisiaca) dengan penambahan level dedak dan lama fermentasi yang berbeda. Hipotesis penelitian ini adalah adanya interaksi antara level dedak dengan lama penyimpanan yang berbeda dalam menurunkan kandungan Neutral Detergent Fiber (NDF), Acid Detergent Fiber (ADF), Acid Detergent Lignin (ADL), serta meningkatkan kandungan hemiselulosa, dan selulosa pada silase kulit pisang kepok.

\section{METODA PENELITIAN}

\section{Bahan dan Alat}

Penelitian ini telah dilaksanakan pada bulan April-September 2016 di Laboratorium Ilmu Nutrisi dan Kimia Fakultas Pertanian dan Peternakan Universitas Islam Negeri Sultan Syarif Kasim Riau Pekanbaru.

Bahan yang digunakan untuk pemeraman adalah dedak dan kulit pisang kepok diperoleh dari pedagang gorengan kawasan Pasar Kampar Kabupaten Kampar. Untuk analisis fraksi serat yang digunakan adalah Aquades, Natrium-Lauryl Sulfat, Tittriplex III, Natrium Borat $10 \mathrm{H}_{2}$, Disodium Hydrogen Phosphate $\left(\mathrm{Na}_{2} \mathrm{HPO}_{4}\right)$, $\mathrm{H}_{2} \mathrm{SO}_{4} 1 \quad \mathrm{~N}$ 1, CTAB (Cetyl-Trimetyl Ammonium Bromide), Oktanol, Alkohol 96\%.

Peralatan yang digunakan untuk proses silase adalah timbangan, pisau, talenan, baskom, plastik hitam dan selotip. Untuk analisis fraksi serat adalah gelas piala $1.000 \mathrm{ml}$, gelas ukur, spatula, pipet tetes, timbangan analitik, fibertec yang dilengkapi dengan hot extraction dan cold extraction, pemanas listrik, oven, tanur dan desikator.

\section{Metode Penelitian}

Penelitian menggunakan Rancangan Acak Lengkap (RAL) pola Faktorial berbentuk kombinasi perlakuan yang terdiri dari 2 faktor yaitu level dedak dengan taraf $0 \%$, 5\%, dan $10 \%$ serta lama pemeraman 0 hari, 14 hari, dan 28 hari dengan 2 ulangan. 
Perlakuan adalah:

A. Kulit pisang kepok + dedak $0 \%$, lama pemeraman 0 hari

B. Kulit pisang kepok + dedak $0 \%$, lama pemeraman 14 hari

C. Kulit pisang kepok + dedak 0\%, lama pemeraman 28 hari

D. Kulit pisang kepok + dedak 5\%, lama pemeraman 0 hari

E. Kulit pisang kepok + dedak 5\%, lama pemeraman 14 hari

F. Kulit pisang kepok + dedak 5\%, lama pemeraman 28 hari

G. Kulit pisang kepok + dedak 10\%, lama pemeraman 0 hari

H. Kulit pisang kepok + dedak 10\%, lama pemeraman 14 hari

I. Kulit pisang kepok + dedak $10 \%$, lama pemeraman 28 hari

Peubah yang diukur adalah komposisi fraksi serat silase kulit buah pisang dengan level dedak dan lama pemeraman yang berbeda meliputi: NDF (\%), ADF (\%), ADL (\%), hemiselulosa (\%) dan selulosa (\%). Data yang diperoleh pada penelitian ini dianalisis dengan analisis sidik ragam (analysis of variance/ANOVA) menggunakan Rancangan Acak Lengkap (RAL) Faktorial. Apabila diperoleh perlakuan berbeda nyata maka dilakukan uji lanjut menggunakan
Duncan's Multiple Range Test (DMRT) (Steel dan Torrie, 1995).

\section{Prosedur Penelitian}

Kulit pisang kepok terlebih dahulu dipotong 3-5 cm menggunakan pisau kemudian dikeringkan pada ruang terbuka, setelah dikeringkan ditimbang kembali untuk mengetahui berat keringnya, selanjutnya ditambahkan dedak sesuai perlakuan adalah $0 \%=0 \mathrm{~g} ; 5 \%=2,19 \mathrm{~g}$ dan $10 \%=4,39 \mathrm{~g}$ dari BK kulit pisang kepok = 43,9 g. Pencampuran bahan dilakukan di dalam baskom dengan mencampurkan kulit pisang kepok dan dedak hingga semua bahan tercampur dengan homogen. Bahan yang telah tercampur homogen kemudian dimasukkan ke dalam kantong plastik hitam dan dipadatkan sehingga mencapai keadaan anaerob, kemudian diikat dan dilapisi selotip serta disimpan selama 0 hari, 14 hari dan 28 hari.

\section{HASIL DAN PEMBAHASAN}

\section{Kandungan Neutral Detergent Fiber (NDF)}

Kandungan NDF silase kulit pisang kepok masing-masing perlakuan dapat dilihat pada Tabel 1 .

Tabel 1. Rataan NDF Silase Kulit Pisang Kepok (\%)

\begin{tabular}{|c|c|c|c|c|}
\hline \multirow{2}{*}{$\begin{array}{c}\text { Level Dedak } \\
(\%)\end{array}$} & \multicolumn{3}{|c|}{ Lama Pemeraman (Hari) } & \multirow{2}{*}{ Rataan } \\
\hline & 0 & 14 & 28 & \\
\hline 0 & $44,71 \pm 14,28$ & $39,49 \pm 9,62$ & $36,15 \pm 4,90$ & $40,11 \pm 4,30$ \\
\hline 5 & $35,77 \pm 0,83$ & $33,61 \pm 0,39$ & $39,52 \pm 9,69$ & $36,30 \pm 2,99$ \\
\hline 10 & $36,85 \pm 4,98$ & $40,13 \pm 8,72$ & $38,11 \pm 1,84$ & $38,36 \pm 1,64$ \\
\hline Rataan & $39,11 \pm 8,05$ & $37,74 \pm 6,63$ & $37,93 \pm 5,15$ & \\
\hline
\end{tabular}

Keterangan : Rataan \pm Standar Deviasi

Level dedak yang berbeda tidak berpengaruh nyata $(\mathrm{P}>0,05)$ terhadap kandungan NDF silase kulit pisang kepok. Hal ini diduga karena substrat yang diberikan belum mampu memproduksi enzim mikroba untuk merombak kandungan NDF. Hal ini sesuai dengan yang dilaporkan Hidayat dkk, (2006) bahwa proses fermentasi meliputi produksi sel mikroba, produksi enzim mikroba, 
produksi hasil metabolism mikroba dan proses transformasi.

Lama pemeraman yang berbeda tidak berpengaruh nyata $(\mathrm{P}>0,05)$ terhadap kandungan NDF silase kulit pisang kepok. Hal ini kemungkinan disebabkan kandungan lignin yang dihasilkan pada penelitian ini juga sama sehingga berpengaruh terhadap hemiselulosa yang dihasilkan. Hemiselulosa merupakan komponen dinding sel yang dapat dicerna oleh mikroba. Crampton dan Haris, (1969) menyatakan tingginya kadar lignin menyebabkan mikroba tidak mampu menguasai hemiselulosa dan selulosa secara sempurna.

Hasil penelitian ini relatif sama dengan yang dilaporkan Astuti dkk., (2015) dimana kandungan NDF kulit pisang dengan penambahan mikro organisme lokal yaitu $47,93 \%-54,65 \%$.

\section{Kandungan Acid Detergent Fiber (ADF)}

Nilai kandungan ADF silase kulit pisang kepok masing-masing perlakuan dapat dilihat pada Tabel 2 .

Tabel 2. Rataan ADF Silase Kulit Pisang Kepok (\%)

\begin{tabular}{crccc}
\hline \multirow{2}{*}{ Level Dedak $(\%)$} & \multicolumn{3}{c}{ Lama Pemeraman (Hari) } & \multirow{2}{*}{ Rataan } \\
\cline { 2 - 4 } & \multicolumn{1}{c}{0} & 14 & 28 & \\
\hline 0 & $36,49 \pm 7,09$ & $31,96 \pm 9,20$ & $28,84 \pm 5,43$ & $32,43 \pm 3,84$ \\
5 & $23,07 \pm 10,87$ & $31,42 \pm 0,93$ & $29,77 \pm 1,39$ & $28,08 \pm 4,42$ \\
10 & $21,69 \pm 12,00$ & $33,26 \pm 6,65$ & $33,93 \pm 1,76$ & $29,62 \pm 6,88$ \\
\hline Rataan & $27,08 \pm 10,77$ & $32,21 \pm 5,16$ & $30,85 \pm 3,57$ & \\
\hline
\end{tabular}

Keterangan : Rataan \pm Standar Deviasi

Level dedak yang berbeda tidak berpengaruh nyata $(\mathrm{P}>0,05)$ terhadap kandungan ADF silase kulit pisang kepok. Hal ini diduga pada saat pemeraman tidak terjadi perenggangan ikatan lignoselulosa dan ikatan hemiselulosa yang dilakukan oleh mikroorganisme. Hal ini sesuai dengan pernyataan Chesson dan Orskov (1984) bahwa beberapa komponen dinding sel tahan terhadap degradasi mikroba an aerob karena berikatan dengan lignin, sehingga komponen ADF tidak banyak terjadi perubahan, akibatnya selulosa yang merupakan komponen penyusun terbesar ADF sukar didegradasi oleh mikroba an aerob.

Lama pemeraman yang berbeda tidak berpengaruh nyata $(\mathrm{P}>0,05)$ terhadap kandungan ADF silase kulit pisang kepok. Hal ini diduga pada proses pemeraman, mikroorganisme belum maksimal melakukan perubahan-perubahan yang dapat memperbaiki mutu pakan, salah satunya adalah penurunanan kandungan ADF. Hal ini sesuai dengan pendapat Winarno dan Fardiaz (1980), bahwa proses fermentasi bahan pakan oleh mikroorganisme menyebabkan perubahanperubahan yang menguntungkan seperti memperbaiki mutu bahan pakan baik dari aspek gizi maupun daya cerna serta meningkatkan daya simpannya. Hasil penelitian ini, kandungan ADF lebih rendah dari yang dilaporkan Zahera (2015) dengan penelitian silase kulit nanas dengan penambahan dedak padi yaitu $38,59 \%$ $42,35 \%$.

\section{Kandungan Acid Detergent Lignin (ADL)}

Nilai kandungan ADL silase kulit pisang kepok masing-masing perlakuan dapat dilihat pada Tabel 3. 
Tabel 3. Rataan ADL Silase Kulit Pisang Kepok (\%)

\begin{tabular}{crrrr}
\hline \multirow{2}{*}{$\begin{array}{c}\text { Level Dedak } \\
(\%)\end{array}$} & \multicolumn{3}{c}{ Lama Pemeraman (Hari) } & \multirow{2}{*}{ Rataan } \\
\cline { 2 - 4 } & \multicolumn{1}{c}{0} & 14 & 28 & \\
\hline 0 & $29,90 \pm 0,40$ & $18,76 \pm 3,39$ & $23,07 \pm 2,72$ & $23,91 \pm 5,61$ \\
5 & $17,30 \pm 13,59$ & $21,95 \pm 7,03$ & $24,99 \pm 0,01$ & $21,41 \pm 3,87$ \\
10 & $14,14 \pm 14,67$ & $27,17 \pm 8,71$ & $27,38 \pm 2,06$ & $22,89 \pm 7,58$ \\
\hline Rataan & $20,45 \pm 11,64$ & $22,62 \pm 6,46$ & $25,14 \pm 2,46$ & \\
\hline
\end{tabular}

Keterangan : Rataan \pm Standar Deviasi

Level dedak yang berbeda tidak berpengaruh nyata $(\mathrm{P}>0,05)$ terhadap kandungan ADL silase kulit pisang kepok. Hal ini diduga lignin mempunyai proporsi karbon yang lebih tinggi dari senyawa karbohidrat yang berasal dari dedak padi sehingga selulosa dan lignin tidak terlepas dari ikatan tersebut oleh enzim lignase, yang berimplikasi tidak terjadi penurunan pada kandungan lignin. Menurut Khairi (2011) degradasi komponen lignoselulosa melibatkan sejumlah enzim seperti peroksidase, selulase dan gula oksidase.

Lama pemeraman yang berbeda tidak berpengaruh nyata $(\mathrm{P}>0,05)$ terhadap kandungan ADL silase kulit pisang kepok. Hal ini diduga bahwa lama pemeraman silase hingga 28 hari, nilai selulosa yang dihasilkan pada penelitian ini sama sehingga lignin yang dihasilkan juga sama. Hal ini sesuai dengan Tillman dkk., (1998) bahwa lignin bersama-sama selulosa membentuk komponen yang disebut lignoselulosa, yang mempunyai koefisien cerna sangat kecil.

Hasil penelitian ini berbeda dengan yang dilaporkan Zahera (2015) bahwa kandungan ADL berbeda nyata antara perlakuan pada silase kulit nanas dengan penambahan dedak padi yaitu $5,43 \%-8,20 \%$. Kandungan ADL yang didapat pada penelitian ini lebih tinggi yaitu $14,14 \%$ $29,90 \%$.

\section{Kandungan Hemiselulosa}

Rataan nilai kandungan hemiselulosa silase kulit pisang kepok masing-masing perlakuan dapat dilihat pada Tabel 4 .

Tabel 4. Rataan Hemiselulosa Silase Kulit Pisang Kepok (\%)

\begin{tabular}{crrrr}
\hline \multirow{2}{*}{$\begin{array}{c}\text { Level Dedak } \\
(\%)\end{array}$} & \multicolumn{3}{c}{ Lama Pemeraman (Hari) } & \multirow{2}{*}{ Rataan } \\
\cline { 2 - 4 } & 0 & 14 & 28 & $7,68 \pm 0,46$ \\
5 & $8,21 \pm 7,18$ & $7,53 \pm 0,42$ & $7,31 \pm 0,53$ & $8,20 \pm 5,42$ \\
10 & $12,69 \pm 11,70$ & $2,18 \pm 1,32$ & $9,74 \pm 8,29$ & $8,72 \pm 5,72$ \\
\hline Rataan & $15,15 \pm 7,02$ & $6,85 \pm 2,05$ & $4,17 \pm 0,07$ & \\
\hline
\end{tabular}

Keterangan: Rataan \pm Standar Deviasi

Level dedak yang berbeda tidak berpengaruh nyata $(\mathrm{P}>0,05)$ terhadap kandungan hemiselulosa silase kulit pisang kepok. Hal ini kemungkinan disebabkan karena bakteri an aerob belum mempunyai kemampuan untuk mendegradasi ikatan lignohemiselulosa pada substrat yang ada sehingga tidak terjadi kenaikan kandungan hemiselulosa. Hal ini sesuai dengan Sutardi dkk., (1980) yang menyatakan bahwa faktor 
yang mempengaruhi degradasi hemi selulosa yaitu adanya ikatan lignin sehingga terbentuk ikatan lignohemiselulosa yang sulit dicerna.

Lama pemeraman yang berbeda tidak berpengaruh nyata $(\mathrm{P}>0,05)$ terhadap kandungan hemiseluosa silase kulit pisang kepok. Hal ini diduga lama pemeraman hingga 28 hari hemiselulosa sangat mudah berikatan dengan lignin membentuk jaringan kompleks dan memberikan struktur yang kuat. Suparjo, (2008) menyatakan hemiselulosa juga berikatan silang dengan lignin membentuk jaringan kompleks dan memberikan struktur yang kuat.

Hasil penelitian ini kandungan hemiselulosa lebih tinggi dari yang dilaporkan Rahmawati (2014) dengan penelitian silase pakan komplit berbahan dasar rumput gajah (Pennisetum purpureum) dan beberapa level biomassa murbei adalah $9,54 \%-11,69 \%$.

\section{Kandungan Selulosa}

Rataan kandungan selulosa silase kulit pisang kepok masing-masing perlakuan dapat dilihat pada Tabel 5.

Tabel 5. Rataan Selulosa Silase Kulit Pisang Kepok (\%)

\begin{tabular}{ccccc}
\hline \multirow{2}{*}{$\begin{array}{c}\text { Level Dedak } \\
(\%)\end{array}$} & \multicolumn{3}{c}{ Lama Pemeraman (Hari) } & \multirow{2}{*}{ Rataan } \\
\cline { 2 - 4 } & 0 & 14 & 28 & $6,61 \pm 4,29$ \\
5 & $2,81 \pm 1,36$ & $11,28 \pm 3,09$ & $5,76 \pm 0,00$ & $5,41 \pm 2,21$ \\
10 & $6,72 \pm 4,08$ & $6,65 \pm 1,26$ & $2,86 \pm 1,32$ & $5,78 \pm 0,25$ \\
\hline Rataan & $5,65 \pm 2,66$ & $6,08 \pm 2,06$ & $5,62 \pm 2,51$ & \\
\hline
\end{tabular}

Keterangan : Rataan \pm Standar Deviasi.

Level dedak yang berbeda tidak berpengaruh nyata $(\mathrm{P}>0,05)$ terhadap kandungan selulosa silase kulit pisang kepok. Hal ini diduga karbohidrat yang dimanfaatkan mikroorganisme tidak mampu menghasilkan enzim selulase yang berfungsi untuk mendegradasi selulosa menjadi glukosa. Hal ini sesuai dengan pendapat Singgih dkk., (2013) bahwa enzim selulase merupakan enzim pencerna komponen serat kasar yang akan meningkatkan nilai kecernaan serat kasar.

Lama pemeraman yang berbeda tidak berpengaruh nyata $(\mathrm{P}>0,05)$ terhadap kandungan selulosa silase kulit pisang kepok. Hal ini diduga lama pemeraman hingga 28 hari menghasilkan enzim-enzim pencerna serat yang belum berfungsi maksimal untuk mendegradasi serat kasar selama proses pemeraman. Widya (2005) menyatakan enzim selulase merupakan salah satu enzim yang dihasilkan oleh mikroorganisme yang berfungsi untuk mendegradasi selulosa menjadi glukosa.

\section{KESIMPULAN}

Penambahan level dedak dan lama pemeraman yang berbeda tidak mampu meningkatkan kandungan hemiselulosa dan selulosa, serta tidak mampu menurunkan kandungan NDF, ADF, dan ADL silase kulit pisang kepok. Tidak terdapat interaksi antara level dedak dan lama pemeraman yang berbeda terhadap kandungan NDF, ADF, ADL, hemiselulosa, dan selulosa silase kulit pisang kepok. 


\section{DAFTAR PUSTAKA}

Astuti, T., Sari, Y., dan Zulkarnani. 2015. Pengaruh Pemeraman Kulit Pisang dengan Mikroorganisme Lokal (MOL) pada Lama Pemeraman dan Sumber MOL yang Berbeda terhadap Kandungan Fraksi Serat sebagai Pakan Ternak. Laporan Penelitian. Fakultas Pertanian Universitas Muara Bungo dan Politani Universitas Andalas. Payakumbuh.

Badan Pusat Statistik. 2014. Produksi Buahbuahan Menurut Jenis Tanaman. http://www.bps.go.id.

Bhia, S., R. Wea., A. Paga., B. Koten. 2015. Pengaruh Lama Pemeraman dengan Nira Lontar terhadap Perubahan Fraksi Serat Kulit Kopi Kering. Jurnal Ilmu Peternakan. 15(1):50-55.

Bolsen K.K. dan Sapienza. 1993. Teknologi Silase : Penanaman, Pembuatan, dan Pemberiannya pada Ternak. Kansas : Pioner Seed.

Chesson, A., and Orskov, E. R. 1984. Mikrobial Degradation in Rumen. In Straw and Other Fibrous by Product as Feed, Elsevier Amsterdam Oxford XIX Tokyo. P: 30-31.

Crampton, E.W. dan L. E. Haris. 1969. Applied Animal Nutrision 1st E. d. The Engsminger Publishing Company, California, U. S. A.

Gunawan, C. 1975. Percobaan Membuat Inokulum Untuk Tempe dan Oncom. Makalah Ceramah Ilmiah LKN. LIPI Bandung. Bandung.

Hidayat, N., M.C.Padaga, dan S. Suhartini. 2006. Mikrobiologi Indutri. Penerbit Andi. Yogyakarta.

Khairi, F. 2011. Kandungan Serat Ransum Komplit dari Limbah Perkebunan Kelapa Sawit dan Agroindustri yang Difermentasi Menggunakan Starbio dengan Lama Fermentasi yang Berbeda. Skripsi. Fakultas Pertanian dan Peternakan UIN Sultan Syarif Kasim Riau. Pekanbaru.
Koni, T., Jublina, B. T., Pieter, R. K. 2013. Pemanfaatan Tepung Kulit Pisang Hasil Pemeraman dengan Jamur Tempe (Rhyzopus aligosporus) dalam Ransum terhadap Pertumbuhan Broiler. Jurnal Veteriner 14 (3): 365-370.

Lynd, L. R., P. J. Weimer., W. H. van Zyl., and I. S. Pretorius. 2002. Microbial cellulose utilization: fundamentals and biotechnology. Microbiol. Mol. Biol. Rev. 66 (3): 506-577.

McDonald, P. 1981. Biochemistry of Silage. Jhon Willey and Sons Inc., New York.

Orlajensen S. 1994. The Lactic Acid Bacteria. Copenhagen: Fred Hostand son.

Rahmawati, 2014. Kandungan ADF, NDF, Selulosa, Hemiselulosa, dan Lignin Silase Pakan Komplit Berbahan Dasar Rumput Gajah (Pennisetum purpureum) dan Beberapa Level Biomassa Murbei (Morus alba). Skripsi. Fakultas Peternakan Universitas Hasanuddin Makasar.

Riswandi. 2014. Kualitas Silase Eceng Gondok (Eichhornia crassipes) dengan Penambahan Dedak Halus dan Ubi Kayu. Jurnal Peternakan 3(1): 1-6.

Singgih, S., Sri, R., Muhamad, B. 2013. Kecernaan Neutral Detergent Fiber (NDF), Acid Detergent Fiber (ADF) dan Serat Kasar Pakan Kerbau Berbasis Jerami Padi. Jurnal Ilmiah Peternakan 1(2): 546-553.

Steel, R. G. D., dan J. H. Torrie. 1995. Prinsip dan Prosedur Statistik. (Diterjemahkan: B. Sumantri). Gramedia Pustaka Utama. Jakarta.

Suparjo. 2008. Degradasi Komponen Lignoselulosa oleh Kapang Pelapuk Putih. Jajo 66.Wordpress.com.

Sutardi, T. 1980. Landasan Ilmu Nutrisi I. Departemen Ilmu Makanan Ternak Fakultas Peternakan Institut Pertanian Bogor. Bogor. 
Tillman, A. D., H. Hartadi, S. Prawirokusumo, dan S. Lebdosoekojo. 1998. Ilmu Makanan Ternak Dasar Cetakan ke-V. Gadjah Mada University Press. Yogyakarta.

Widya. 2005. Enzim Selulase. http://kb.atmajaya.ac.id/default. aspx? tab $\mathrm{ID}=61 \& \mathrm{src}=\mathrm{a} \& \mathrm{id}=84059$.
Winarno, F.G. dan S. Fardiaz. 1980. Pengantar Teknoologi Pangan. Gramedia. Pustaka Utama. Jakarta.

Zahera, R. 2015. Pengaruh Komposisi Substrat dan Dedak Padi terhadap Kandungan Fraksi Serat Silase Mahkota Nanas. Skripsi. Fakultas Pertanian dan Peternakan, Universitas Islam Negeri Sultan Syarif Kasim Riau. Pekanbaru 